\title{
Microvascular endothelial dysfunction: a renewed appreciation of sepsis pathophysiology
}

Jean-Louis Vincent

Erasme University Hospital, Free University of Brussels, Brussels, Belgium

Correspondence: Professor J-L Vincent, Department of Intensive Care, Erasme University Hospital, Route de Lennik 808, 1070 Brussels, Belgium. Tel: +32 2555 3380; fax: +32 2555 4555; e-mail: jlvincen@ulb.ac.be

Received: 17 January 2001

Accepted: 22 February 2001

Published: 8 March 2001
Critical Care 2001, 5:S1-S5

(C) 2001 BioMed Central Ltd

(Print ISSN 1364-8535; Online ISSN 1466-609X)

\begin{abstract}
Severe sepsis, defined as sepsis associated with acute organ dysfunction, results from a generalized inflammatory and procoagulant host response to infection. Coagulopathy in severe sepsis is commonly associated with multiple organ dysfunction, and often results in death. The molecule that is central to these effects is thrombin, although it may also have anticoagulant and antithrombotic effects through the activation of Protein $\mathrm{C}$ and induction of prostacyclin. In recent years, it has been recognized that chemicals produced by endothelial cells play a key role in the pathogenesis of sepsis. Thrombomodulin on endothelial cells coverts Protein $\mathrm{C}$ to Activated Protein C, which has important antithrombotic, profibrinolytic and anti-inflammatory properties. A number of studies have shown that Protein $\mathrm{C}$ levels are reduced in patients with severe infection, or even in inflammatory states without infection. Because coagulopathy is associated with high mortality rates, and animal studies have indicated that therapeutic intervention may result in improved outcomes, it was rational to initiate clinical studies.
\end{abstract}

Keywords: Activated Protein C, antithrombotic, coagulation, endothelial cells, fibrinolysis, inflammation, organ dysfunction, sepsis

\section{Introduction}

Sepsis, the host response to infection, involves a series of clinical, hematological, inflammatory and metabolic responses that can ultimately lead to organ failure. Severe sepsis is typically associated with activation of the coagulation system, leading to deposition of thrombin in the microvasculature. This process is associated first with activation, and then with inhibition of fibrinolysis. It is also associated with an inflammatory response and changes in microvascular permeability. These alterations, which are recognized by the clinician as disseminated intravascular coagulation (DIC), are commonly associated with multiple organ dysfunction, and have important prognostic implications. DIC, therefore, can be seen as both a thrombotic and a bleeding disorder, as an index of disease severity, or as an inflammatory disorder.

\section{Interaction of coagulation and inflammation}

It is now recognized that acute sepsis involves a complex interaction between the coagulation system and the inflammatory system that may result in organ dysfunction. The molecule that may be considered central to these effects is thrombin. In addition to its well-known procoagulation effects, thrombin may have anticoagulation effects through Protein $\mathrm{C}$ activation and induction of prostacyclin (Fig. 1). Thrombin may also cause cell proliferation and inflammation through induction of adhesion molecules and platelet-activating factor activation.

$\mathrm{ATIII}=$ antithrombin III; DIC $=$ disseminated intravascular coagulation; PAI = plasminogen activator inhibitor; TF $=$ tissue factor; TNF $=$ tumour necrosis factor. 
Figure 1

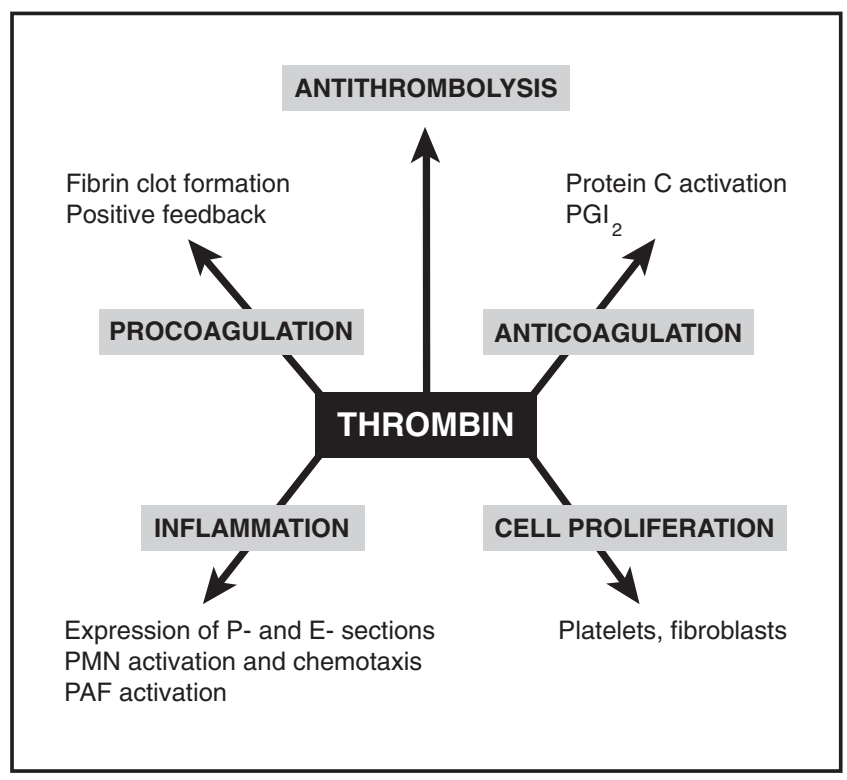

Central role of thrombin in acute sepsis. PAF, platelet-activating factor; $\mathrm{PGI}_{2}$, prostacyclin; $\mathrm{PMN}$, polymorphonuclear leukocyte.

The interaction between coagulation and inflammation has been demonstrated in a number of animal studies in which anticoagulant therapies, including heparin [1,2], antithrombin [3,4], tissue factor (TF) pathway inhibitor [5-7] and Activated Protein C [8], were shown to influence the inflammatory response. It is also now clear that both the coagulation and the fibrinolytic systems may be altered in acute sepsis, with the balance tipped in favour of procoagulation (through increased TF and thrombin expression, with decreased activation of thrombomodulin and Protein C) and antifibrinolysis (through plasminogen activator inhibitor [PAI]-1 expression). In experimental models in which very small doses of endotoxin or tumour necrosis factor (TNF) are given to volunteers, there is initially a profibrinolytic response, followed by an antifibrinolytic response, which corresponds to a procoagulant state (Fig. 2).

Considering the coagulation cascade as a whole, it is the extrinsic pathway (via TF and thrombin activation) rather than the intrinsic pathway that is of primary importance in sepsis. Once coagulation has been triggered by TF activation, leading to thrombin formation, this can have further procoagulant effects, because thrombin itself can activate factors VIII, IX and X. This is normally balanced by the production of anticoagulant factors, such as TF pathway inhibitor, antithrombin and Activated Protein C. However, there are other contributors to the processes of pro-/anticoagulation and inflammation, including monocytes, macrophages, platelets and, importantly, endothelial cells.
Figure 2

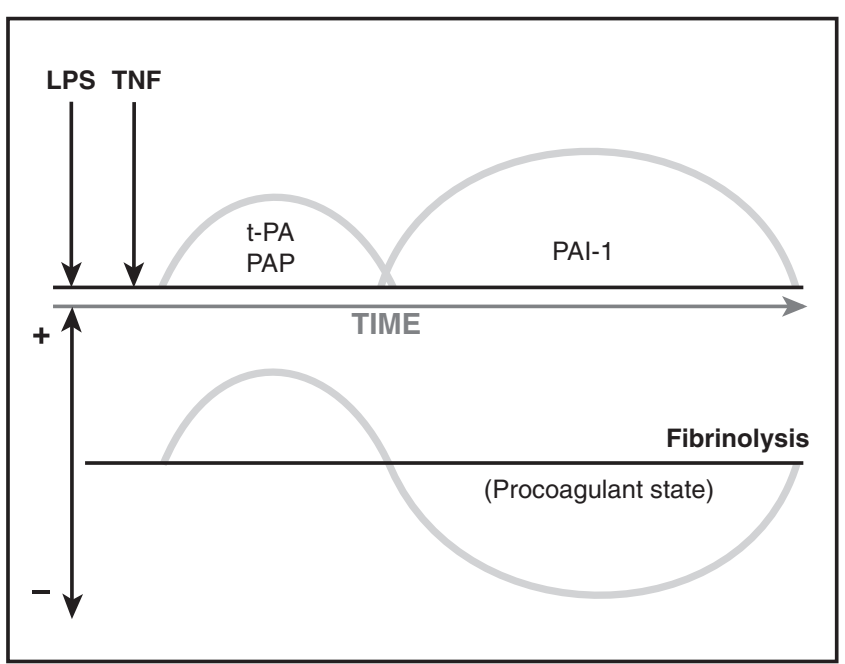

Experimental model of sepsis in volunteers: Effect of small doses of endotoxin (lipopolysaccharide [LPS]) or TNF on the fibrinolysis system. PAP, plasmin-antiplasmin complex; t-PA, tissue plasminogen activator.

\section{Role of endothelial cells}

In recent years, it has been recognized that endothelial cells play a key role in the pathogenesis of sepsis, and that they produce important regulators of both coagulation and inflammation. They can express or release a number of substances, such as TF, endothelin-1 and PAl-1, which promote the coagulation process, as well as other substances, such as antithrombin, thrombomodulin, nitric oxide and prostacyclin, which inhibit it (Fig. 3). Thrombomodulin is to anticoagulation what TF is to coagulation. That is, the binding of thrombin to thrombomodulin on endothelial cells results in Protein $\mathrm{C}$ activation. Once activated, Protein $\mathrm{C}$ binds to its cofactor, Protein $\mathrm{S}$ (either freely circulating or bound to C4b-binding protein), and Activated Protein $C$ inhibits the coagulation factors $V a$ and VIlla. Activated Protein C may also neutralize PAl-1, resulting in increased fibrinolysis, which represents an important difference between Activated Protein $\mathrm{C}$ and other anticoagulant substances, such as antithrombin. Activated Protein $\mathrm{C}$ also has important anti-inflammatory properties. It may inhibit E-selectin-mediated cell adhesion, or generation of interleukin-1 and TNF by monocytes, and may also uncouple the lipopolysaccharide (endotoxin) interaction with CD14 receptors.

\section{Decreased Protein $C$ in disease}

Protein C is the source of Activated Protein C. Although Protein $C$ is a biomarker or indicator of sepsis, it has no known specific biological activity. Protein $\mathrm{C}$ is converted to Activated Protein $\mathrm{C}$ in the presence of normal endothelium. In patients with severe sepsis, the vascular endothelium becomes damaged, levels of endothelial 


\section{Figure 3}

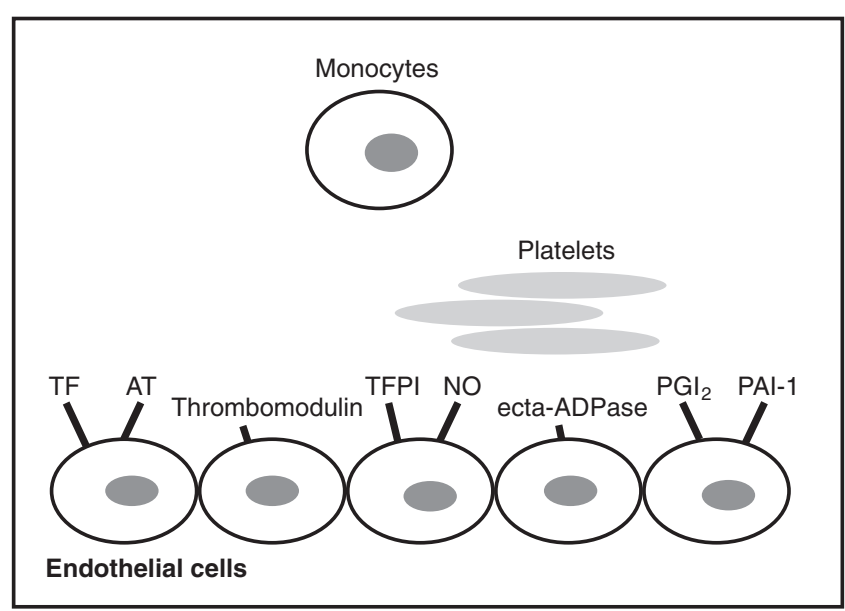

Procoagulant and anticoagulant substances that are expressed/released by endothelial cells. AT, antithrombin; NO, nitric oxide; $\mathrm{PGI}_{2}$, prostacyclin; TFPI, TF pathway inhibitor.

thrombomodulin significantly decrease, and the body's ability to convert Protein $\mathrm{C}$ to Activated Protein $\mathrm{C}$ diminishes. Only when activated does Protein $\mathrm{C}$ have antithrombotic, profibrinolytic and anti-inflammatory properties.

A number of studies have now shown that Protein $C$ levels are reduced in patients with severe infection. In the study by Powars et al [9], Protein C levels were reduced to approximately $50 \%$ of normal levels in patients with moderate meningococcaemia, and to approximately $30 \%$ of normal levels in critically ill patients (Fig. 4). Similarly, a study by Hemmer et al [10] in patients with malaria showed that those with complications had much higher levels of TNF and greatly reduced Protein C activity (Fig. 5). In patients who have undergone bone marrow transplantion, low antithrombin and Protein $\mathrm{C}$ levels are also the best predictors of multiple organ dysfunction [11]. In a subgroup of 70 patients with sepsis included in an ibuprofen trial [12], 90\% were shown to have low Protein $\mathrm{C}$ levels and most also had other alterations in coagulation factors (elevated D-dimers, low fibrinogen level and low platelet count). In that study, there was a significant correlation between the increase in Protein $\mathrm{C}$ levels from 0 to $44 \mathrm{~h}$, and 30-day mortality $(P<0.01)$. Furthermore, mortality was higher in patients with persistently low Protein $C$ levels than in those whose Protein $\mathrm{C}$ levels recovered spontaneously without any treatment (45\% versus $26 \%)$.

Coagulation abnormalities can occur in all types of infection, including both Gram-positive and Gram-negative bacterial infections [13-15], or even in the absence of infection, such as in inflammatory states secondary to trauma or neurosurgery [16]. Interestingly, they can also occur in patients with localized disease, such as those with
Figure 4

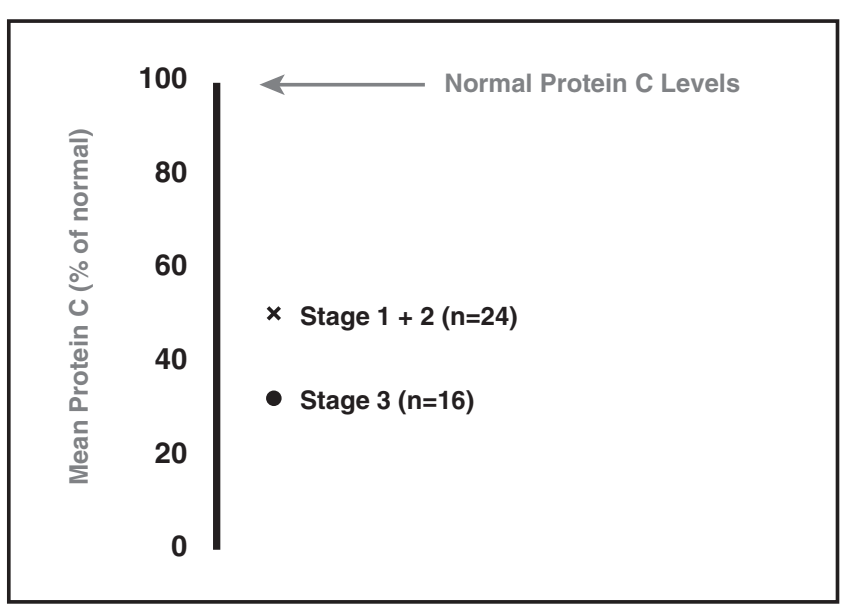

Protein $\mathrm{C}$ levels (\% of normal) in patients with meningococcaemia. Adapted from Powars et al [9].

\section{Figure 5}

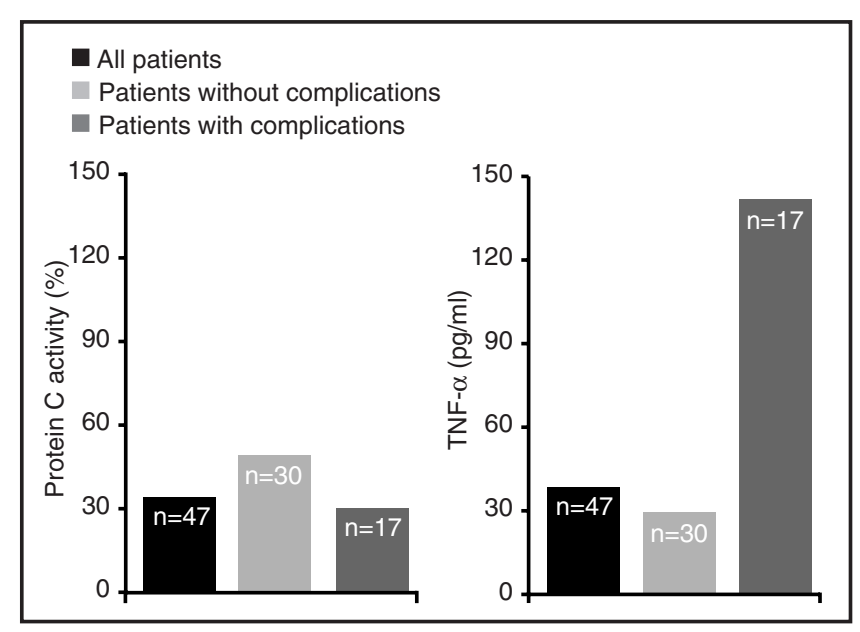

TNF- $\alpha$ levels (normal range $<15 \mathrm{pg} / \mathrm{ml}$ ) and Protein $\mathrm{C}$ activity (normal range $60-140 \%$ ) in malaria. Adapted from Hemmer et al [10].

respiratory infection [17]. In a study by Günther et al [17], procoagulant activity in bronchial lavage fluid from patients with pneumonia or acute respiratory distress syndrome was found to be increased compared with that from control individuals, with a correlation between the severity of respiratory failure and level of coagulant activity (Fig. 6).

\section{Rationale for clinical studies}

It is well documented that DIC in septic shock is associated with higher mortality rates than is septic shock without DIC (77\% versus 32\%) [18]. Higher Sequential Organ Failure Assessment scores [19] and PAl-1 levels 


\section{Figure 6}

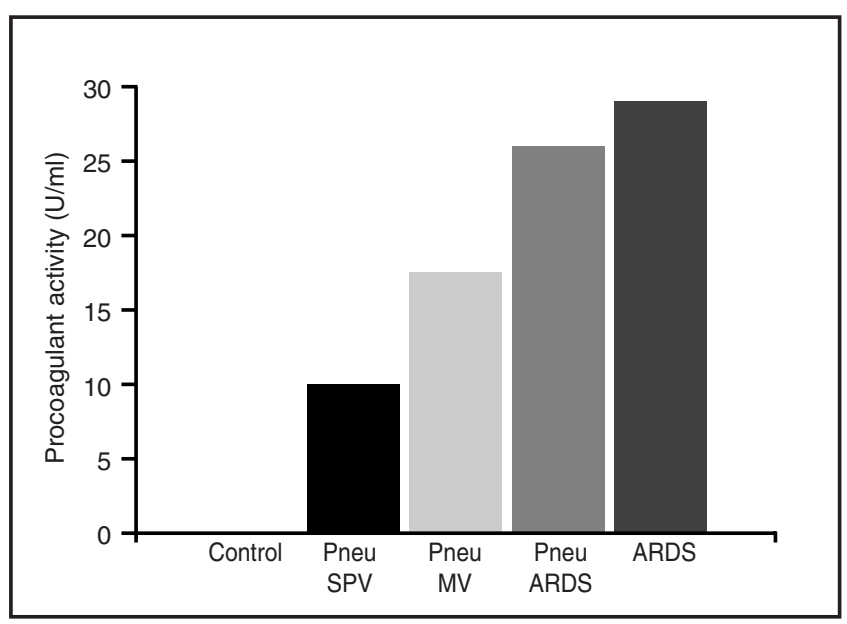

Coagulation abnormalities in pneumonia (Pneu) and acute respiratory distress syndrome (ARDS; $n=222$ ). SPV, spontaneous ventilation; $\mathrm{MV}$, mechanical ventilation. Adapted from Günther et al [17].

[20] have also been correlated with increased mortality. Furthermore, coagulation is inter-related with inflammation. Because animal studies indicated that therapeutic intervention may result in improved outcome, a number of clinical studies were initiated.

\section{Recent clinical studies with antithrombin and Activated Protein C}

Early clinical studies with antithrombin III (ATIII) achieved promising results. In a study by Fourrier et al [21], patients who were treated with ATIII had a shorter duration of DIC with no side effects, and no change in Protein $\mathrm{C}$ or Protein $\mathrm{S}$ levels. However, a meta-analysis of three placebo-controlled, randomized clinical trials with ATIII in sepsis [22] demonstrated a nonsignificant reduction in 30-day allcause mortality. A phase II clinical trial has identified the optimum dosage regimen for recombinant human Activated Protein $\mathrm{C}$, and this has subsequently been used in a large, multicenter, placebo-controlled, phase III trial.

\section{Conclusion}

Severe sepsis, defined as sepsis associated with acute organ dysfunction, results from a generalized inflammatory and procoagulant host response to infection. The ultimate cause of acute organ dysfunction in sepsis is injury to the vascular endothelium, which can result in microvascular coagulopathy.

The extrinsic pathway (via TF and thrombin activation) is of primary importance in sepsis. Thrombomodulin on endothelial cells converts Protein $\mathrm{C}$ to Activated Protein $\mathrm{C}$, which has multiple mechanisms of action that support its antiinflammatory, antithrombotic and profibrinolytic properties. In patients with severe sepsis, the vascular endothelium becomes damaged, levels of endothelial thrombomodulin significantly decrease, and the body's ability to convert Protein $\mathrm{C}$ to Activated Protein $\mathrm{C}$ diminishes.

The complex interactions between coagulation and inflammation support the development and use of strategies that are aimed at improving endothelial cell function, and thus providing therapeutic intervention to modulate inflammation and coagulopathy in patients with sepsis and organ dysfunction. Early clinical studies using recombinant human Activated Protein C appear promising.

\section{References}

1. Hau T, Simmons RL: Heparin in the treatment of experimental peritonitis. Ann Surg 1978, 187:294-298.

2. Chalkiadakis G, Kostakis A, Karayannacos PE, Giamarellou H, Dontas I, Sakellariou I, Skalkeas GD: The effect of heparin upon fibrinopurulent peritonitis in rats. Surg Gynecol Obstet 1983, 157:257-260.

3. Emerson TE Jr, Fournel MA, Redens TB, Taylor FB Jr: Efficacy of antithrombin III supplementation in animal models of fulminant Escherichia coli endotoxemia or bacteremia. Am J Med 1989, 87(suppl B):27S-33S.

4. Triantaphyllopoulos DC: Effects of human antithrombin III on mortality and blood coagulation induced in rabbits by endotoxin. Thromb Haemost 1984, 51:232-235.

5. Taylor FB Jr, Chang A, Ruf W, Morrissey JH, Hinshaw L, Catlett R, Blick K, Edgington TS: Lethal $E$. coli septic shock is prevented by blocking tissue factor with monoclonal antibody. Circ Shock 1991, 33:127-134.

6. Levi M, ten Cate H, Bauer KA, van der Poll T, Edgington TS, Buller HR, van Deventer SJ, Hack CE, ten Cate JW, Rosenberg RD: Inhibition of endotoxin-induced activation of coagulation and fibrinolysis by pentoxifylline or by a monoclonal anti-tissue factor antibody in chimpanzees. J Clin Invest 1994, 93:114-120.

7. Dackiw AP, McGilvray ID, Woodside M, Mathens AB, Marshall JC Rotstein OD: Prevention of endotoxin-induced mortality by antitissue factor immunization. Arch Surg 1996, 131:1273-1278.

8. Taylor FB Jr, Chang A, Esmon CT, D'Angelo A, Vigano-D'Angelo $S$, Blick KE: Protein C prevents the coagulopathic and lethal effects of Escherichia coli infusion in the baboon. J Clin Invest 1987, 79:918-925.

9. Powars D, Larsen R, Johnson J, Hulbert T, Sun T, Patch MJ, Francis R, Chan L: Epidemic meningococcemia and purpura fulminans with induced protein C deficiency. J Infect Dis 1993, 17:254-261.

10. Hemmer CJ, Kern P, Holst FG, Radtke KP, Egbring R, Bierhaus A, Nawroth PP, Dietrich M: Activation of the host response in human Plasmodium falciparum malaria: relation of parasitemia to tumor necrosis factor/cachectin, thrombin-antithrombin III, and protein C levels. Am J Med 1991, 91:37-44.

11. Haire WD, Ruby El, Gordon BG, Patil KD, Stephens LC, Kotulak GD, Reed EC, Vose JM, Bierman PJ, Kessenger A, et al: Multiple organ dysfunction syndrome in bone marrow transplantation. $J$ Am Med Assoc 1995, 274:1289-1295.

12. Yan SB, Helterbrand JD, Hartman DL, Wright TJ, Bernard GR: Low levels of protein $C$ are associated with poor outcome in severe sepsis: acquired protein $C$ deficiency state in sepsis. Crit Care Med 2001, in press.

13. Kalter ES, van Dijk WC, Timmerman A, Verhoef J, Bouma BN: Activation of purified human plasma prekallikrein triggered by cell wall fractions of Escherichia coli and Staphylococcus aureus. J Infect Dis 1983, 4:682-691.

14. Molla A, Yamamoto T, Akaike T, Miyoshi S, Maeda H: Activation of hageman factor and prekallikrein and generation of kinin by various microbial proteinases. J Biol Chem 1989, 264: 10589-10594.

15. Mavrommatis AC, Theodoridis T, Orfanidoui A, Roussos C, Christopoulou-Kokkinou V, Zakynthinos S: Coagulation system and platelets are fully activated in uncomplicated sepsis. Crit Care Med 2000, 28:451-457. 
16. Boldt J, Papsdorf M, Rothe A, Kumle B, Piper S: Changes of the hemostatic network in critically ill patients: is there a difference between sepsis, trauma, and neurosurgery patients? Crit Care Med 2000, 28:445-450.

17. Günther A, Mosavi $P$, Heinemann $S$, Ruppert $C$, Muth $H$, Markart $P$, Grimminger F, Walmrath D: Alveolar fibrin formation caused by enhanced procoagulant and depressed fibrinolytic capacities in severe pneumonia. Comparison with the acute respiratory distress syndrome. Am J Respir Crit Care Med 2000, 161:454-462.

18. Fourrier F, Chopin C, Goudemand J, Hendryex S, Caron C, Rime A, Marey A, Lestavel P: Septic shock, multiple organ failure, and disseminated intravascular coagulation. Compared patterns of antithrombin III, protein $\mathrm{C}$, and protein $\mathrm{S}$ deficiencies. Chest 1992, 101:816-823.

19. Vincent JL, Moreno R, Takala J, Willatts S, De Mendonca A, Bruining H, Reinhart CK, Suter PM, Thijs LG: The SOFA (Sepsisrelated Organ Failure Assessment) score to describe organ dysfunction/failure. Intensive Care Med 1996, 22:707-710.

20. Kornelisse RF, Hazelzet JA, Savelkoul HF, Hop WC, Suur MH, Borsboom AN, Risseeuw-Appel IM, van der Voort E, de Groot R: The relationship between plasminogen activator inhibitor-1 and proinflammatory and counterinflammatory mediators in children with meningococcal septic shock. J Infect Dis 1996, 173:1148-1156.

21. Fourrier F, Chopin C, Huart JJ, Runge I, Caron C, Goudemand J: Double-blind, placebo-controlled trial of antithrombin III concentrates in septic shock with disseminated intravascular coagulation. Chest 1993, 104:882-888.

22. Fourrier $F$, Jourdain $M$, Tournoys $A$ : Clinical trial results with antithrombin III in sepsis. Crit Care Med 2000, 28(9 suppl): S38-S43. 